\title{
The job satisfaction-productivity nexus: A study using matched survey and register data
}

\author{
Petri Böckerman \\ Labour Institute for Economic Research \\ and University of Tampere \\ and \\ Pekka Ilmakunnas \\ Aalto University and HECER
}

Discussion Paper No. 297

June 2010

ISSN 1795-0562

HECER - Helsinki Center of Economic Research, P.O. Box 17 (Arkadiankatu 7), FI-00014 University of Helsinki, FINLAND, Tel +358-9-191-28780, Fax +358-9-191-28781, E-mail info-hecer@helsinki.fi, Internet www.hecer.fi 


\title{
The job satisfaction-productivity nexus: A study using matched survey and register data
}

\begin{abstract}
We examine the role of job satisfaction in the determination of establishment-level productivity. Our matched data contain both information on job satisfaction from ECHP (European Community Household Panel) and information on establishment productivity from longitudinal register data that can be linked to the ECHP. The estimates for the effect of one point increase in the establishment average level of employee job satisfaction, on a scale $1-6$, on productivity vary depending on the specification of the model. Our preferred estimate, based on the IV estimation that uses satisfaction with housing conditions as instrument for job satisfaction, shows that the effect on value added per hours worked is roughly 20 percent in the manufacturing sector. The economic size of this effect is smaller, because the observations are bunched towards the higher end of the satisfaction scale making it difficult to increase the average level of job satisfaction in the establishment by one point. An increase in job satisfaction by one within-establishment standard deviation would increase productivity by 6 percent.
\end{abstract}

JEL Classification: D24, J28

Keywords: job satisfaction, employee well-being, productivity, firm performance.

Petri Böckerman

Labour Institute for Economic Research

Pitkänsillanranta $3 \mathrm{~A}$

FI-00530 Helsinki

FINLAND

e-mail: petri.bockerman@labour.fi
Pekka IImakunnas

Department of Economics

Aalto University

P.O. Box 21240

FI-00076 Aalto

FINLAND

e-mail: pekka.ilmakunnas@hse.fi

* This study is funded by the Finnish Work Environment Fund and the Palkansaajasäätio Foundation. The data used in this study are confidential and can be accessed on site at the Research Laboratory of the Business Structures Unit of Statistics Finland. The computer programs to generate the results are available from the first author. We are grateful to Antti Kauhanen and participants at the Conference on Econometrics of Healthy Human Resources in Rome for comments. 


\section{Introduction}

Job satisfaction is an important attribute of all labor market matches, as it is a useful summary measure of utility at work. The effects of job satisfaction on various labor market outcomes have been widely explored in the literature (e.g. Freeman 1978; Clark et al. 1998). Despite this, there are still relatively neglected areas of research. One of those concerns the effect of employees' job satisfaction on firms' performance. Job satisfaction can have a positive effect on performance, if it increases effort e.g. by reducing employee shirking and superfluous on-the-job activities. The issue has been at a high place in the policy agenda. For example, European Union argues in its Lisbon strategy that job satisfaction positively contributes to firms' performance. This is a rather provocative claim, because it implies that policies to improve job satisfaction would be beneficial for both employees and employers.

The empirical evidence on the relationship between job satisfaction and productivity is quite sketchy owing to the lack of suitable data. The connection between job satisfaction and productivity is also challenging to identify, because job satisfaction is only one of the many different factors that affect firms’ productivity. Judge et al. (2001) perform a metaanalysis covering 312 samples with a combined number of observations of 54 417. The mean correlation between job satisfaction and job performance is estimated to be 0.30 . The $80 \%$ confidence intervals range from 0.03 to 0.57 . Some of the highest estimates are likely to be caused by the fact that establishment characteristics are not controlled for in all studies. Furthermore, the causal effect of job satisfaction is difficult to establish, as there may be reverse causality from firm performance to job satisfaction.

We contribute to the literature on several frontiers. First, we use the standard measures of productivity as the dependent variables. The literature has typically used various proxy variables for productivity. One of the earliest quantitative studies relied on the use of medicines by employees as a measure of their productivity (Mangione and Quinn 1975). Other studies have used the prevalence of sickness absence as the measure of firms' performance (e.g. Glegg 1983) or relied on the evaluations made by supervisors about their employees’ performance (Iaffaldano and Muchinsky 1985; Judge et al. 2001; Zelenski et al. 2008). ${ }^{1}$ It has also been common to use customers' satisfaction scores in the studies that focus on the service sector. However, it is evidently difficult to detect the underlying 
connection by using subjective measures on the both sides of the estimated equation (Hamermesh 2004). In particular, the use of satisfaction scores reported by supervisors or customers as the dependent variable means that satisfaction is essentially explained by satisfaction. Instead of these kinds of proxies, we use more conventional measures of establishment productivity. Labor productivity in the manufacturing sector is defined as valued added per hours worked. In manufacturing we also use an index of total factor productivity. In the models that include the private service sector we use turnover per employee as our performance measure. The use of these standard measures of productivity is possible, because our longitudinal survey data on job satisfaction can be linked to the establishment-level register data by using unique establishment identifiers.

Second, we use data that is representative in the private sector. Most of the earlier studies that have estimated the relationship between job satisfaction and productivity have focused only on some firms or narrow sectors of the economy (Patterson et al. 1997; Harter et al. 2002; Schneider et al. 2003; Patterson et al. 2004). This makes it rather hard to generalize the results obtained. For example, Harter et al. (2002) derive their set of estimates for the U.S. economy by using data that covers 36 firms. The estimates for the narrow sectors could be subject to severe selection bias, if the unobserved factors that determine whether employees choose to work in the sector also influence their subsequent performance at work.

Our third contribution to the existing knowledge is built on the fact that we use panel data that contain measures of job satisfaction for each year of the data. Most of the earlier studies have relied on cross-sectional data that offer only scanty opportunities to address the underlying causal relationship. ${ }^{2}$ Thus, the literature has focused on the correlations between the variables of interest (see Judge et al. 2001, for a survey). On the contrary, we implement an instrumental variable estimator that addresses the concern about the endogeneity of job satisfaction in the estimated equation. This allows us to evaluate the validity of the estimates that have relied on the assumption about the exogeneity of job satisfaction. Another reason for the use of IV estimator is the possible measurement error in job satisfaction. In this paper, we use employees' satisfaction with their housing conditions as instrument for job satisfaction. Finally, we also apply a variation of the method introduced by Olley and Pakes (1996). The method is able to tackle for both simultaneity of job satisfaction and performance, and selection of set of firms over time. 
We examine the connection between employees' job satisfaction and establishments' productivity with Finnish data. Our rather unique data set comes from a merge of two data sets. The first one is the Finnish part of the European Community Household Panel (ECHP). ECHP contains information on individual satisfaction. ECHP is matched to longitudinal, register-based employer-employee data maintained by Statistics Finland. This makes it possible to calculate productivity for the establishments from which there are employees interviewed in the ECHP. We estimate models for productivity using the measure of average job satisfaction in the establishment as our main explaining variable. We are able to control for several establishment characteristics such as the average age of employees by using register-based information. Our paper is most closely related to the ones by Black and Lynch (2001) and Buhai et al. (2008). Black and Lynch (2001) explore the effects of workplace practices and information technology, while Buhai et al. (2008) focus on the impacts of working conditions on firm performance. Buhai et al. (2008) use Danish data that contain the measures of working conditions for one year and they rely mostly on GMM panel data estimates that use lagged variables as instruments.

\section{Data}

We use the European Community Household Panel (ECHP) for Finland over the period 1996-2001. ${ }^{3}$ The ECHP is based on a standardised questionnaire that contains annual interviews of a representative panel of households and individuals in each European Union country (e.g. Peracchi 2002). The ECHP is composed of a separate personal file and a separate household file. We use the data from the personal file, because it is the file that contains information on employees' subjective well-being. One's job satisfaction status is an answer to the question on satisfaction with work or main activity. Job satisfaction is measured on an ordinal 6-point Likert scale from 'not satisfied' to 'fully satisfied'. A higher value on this scale means that a person currently feels more satisfied. The observations on job satisfaction are concentrated towards the higher end of the scale (Figure 1), which is a wellknown feature of the variables that measure employees’ utility at work (e.g. Clark 1996). This pattern has to be taken into account in the interpretation of the estimates. We use the ECHP to calculate the average job satisfaction level for each establishment from which there is at least one response to the question on job satisfaction. 
Figure 1 here

The fact that the ECHP for Finland can be matched to longitudinal register data, FLEED (Finnish Longitudinal Employer-Employee Data) is essential for our purposes. Matching of the data sources is possible, because all data sets that we use contain the same unique identifiers for persons and establishments. FLEED is constructed from a number of different registers on individuals, firms and their establishments that are maintained by Statistics Finland (SF). FLEED contains detailed information on employee characteristics from Employment Statistics (ES). We use this information to calculate the average employee characteristics for each establishment, which are then used as control variables in the models for productivity. The average employee characteristics are calculated for all those establishments from which there are at least five persons in ES. ES is also used to calculate the annual worker outflow measures for each plant that are then used with the Olley-Pakes approach, as explained later.

Information on value added, hours worked, capital stock and export status originate from the Longitudinal Database on Plants in Finnish Manufacturing (LDPM) of SF. LDPM includes all plants in the manufacturing sector owned by the firms that have no fewer than 20 persons from 1995 onwards.

We use three different measures of productivity as the dependent variables. Our primary productivity measure is value added per hours worked in the plant. This measure of labor productivity is based on LDPM. To calculate total factor productivity for the manufacturing plants, we use industry-level information on the labor share of the value added taken from EU-KLEMS database. ${ }^{4}$ Total factor productivity is defined as follows: $\ln T F P=\ln (Y / L)-(1-$ a) $\ln (K / L)$, where $a$ is the labor share of the value added. $Y / L$ and $K / L$ for each plant originate from LDPM. The correlation coefficient between total factor productivity and value added per hours worked is 0.47 in manufacturing. (Significant at the $1 \%$ level.) Our third performance measure that captures turnover per employee is taken from the Business Register of SF. Its main advantage is that it is available also for the private service sector. This increases the sample size considerably, because we are able to include nonmanufacturing establishments to the models. The correlation coefficient between turnover per employee and value added per hours worked is 0.58 in the manufacturing sector. (Significant at the 1\% level.) Therefore, the three measures capture partly different aspects 
of establishment performance. The exact definitions including the means and standard deviations of the variables are documented in the Appendix (Table A1).

\section{Modeling approaches}

The baseline OLS models have the following structure:

$$
\operatorname{lnProd}_{j t}=\alpha_{\mathrm{j}}+\beta_{j 1} J S_{j t}+\boldsymbol{\beta}_{j 2} \boldsymbol{X}_{j t}+\varepsilon_{j t}
$$

where Prod is our measure of productivity (valued added per hours worked, total factor productivity or turnover per employee) for the establishment $j$ in the year $t$. The variable of our interest is JS (job satisfaction) which is the average satisfaction score for the establishment $j$ in the year $t$ for all those establishments from which there is at least one employee in the ECHP. We use the average job satisfaction scores over the period $t, t-1$ and $t-2$ for the establishments as the explanatory variable in all models, because there are relatively small number of observations for each establishment on job satisfaction that may cause measurement error. ${ }^{5}$ Mairesse and Greenan (1999) point out that the OLS estimate is downward biased when there are only few observations on employee characteristics for each establishment in the combined data, but the corresponding t-value for the hypothesis that the effect for the employee character is zero remains unbiased under the null hypothesis of zero effect even when there is only one employee observation per establishment. Thus, it is possible to make valid conclusions for the significance of the effect by using OLS. $\boldsymbol{X}_{j t}$ is the vector of control variables. It includes a set of establishment characteristics such as the average age of employees and the average years of education in the establishment, among other factors. To account for the unobservable establishmentlevel heterogeneity we also estimate the model by using establishment fixed effects $\left(\alpha_{\mathrm{j}}\right)$.

As another approach to eliminate the time-invariant establishment effects, we follow Black et al. (2001:441) and Buhai et al. (2008:15-16). We prefer the use of 2-stage approach to conventional fixed effects estimation, because there is not much variation in job satisfaction over time and this variation is further decreased after taking within establishment differences in conventional fixed effects estimation. In the first stage a measure of productivity is explained by the time-variant establishment-level characteristics and a set of indicators for years, industries and regions in fixed effects estimation. We take the residual 
from the first stage, averaged over time (i.e. the time-invariant component of the residual) and use it as the dependent variable in the second stage of estimation. The explanatory variable in the second stage is the average level of job satisfaction in the establishment over the period $t, t-1$ and $t$-2. This approach takes care of all time-invariant establishment effects that are potentially correlated with the choice of establishment's inputs in the first stage.

We also implement an instrumental variable estimator, because the central cause of concern is that job satisfaction is potentially endogenous in the equation (1). We use employees' satisfaction with their housing conditions as instrument for job satisfaction, as noted in the introduction. We implement the estimator by using two-stage least squares approach. The equation of interest describing the effect of job satisfaction on productivity is identical to the equation (1). The first-stage regression equation is

$$
J S_{j t}=\beta_{j 1} H S_{j t}+\boldsymbol{\beta}_{j 2} \boldsymbol{X}_{j t}+\varepsilon_{j t}
$$

where the term (HS) is the employees' average satisfaction with their housing conditions for those being employed in the establishment $j$ in the year $t$. HS is calculated for all those establishments from which there is at least one employee interviewed in the ECHP. HS is omitted from the second-stage equation. The answers on satisfaction with housing conditions in the ECHP are measured similarly to job satisfaction on an ordinal 6-point Likert scale from 'not satisfied' to 'fully satisfied'. A higher value on this scale means that a person currently feels more satisfied with housing conditions.

For satisfaction with housing conditions to be a valid instrument it must be correlated with job satisfaction, but it must not be a determinant of establishments' productivity, i.e. it must be uncorrelated with the error term in the equation for productivity. Thus, job satisfaction must have no influence on establishments' productivity other than through the first-stage channel. We cannot perform overidentification tests for the exogeneity of the instrument because we are using only one instrument. However, one can imagine only rather extreme examples in which the assumption about satisfaction with housing conditions being uncorrelated with the productivity equation residual could clearly be violated. For example, in an economy that consists of great number of islands with one plant and their employees located in each island and employees living in employer-provided houses there would probably be a connection between satisfaction with housing conditions and productivity 
through other channels than job satisfaction. We expect that there exists a positive correlation between job satisfaction and satisfaction with housing conditions, based on the psychology literature. In particular, the positive correlation that constitutes the basis for the relevance of the instrument is in accordance with the well-known "spillover hypothesis" (e.g. Wilensky 1960; Rain et al. 1991). This notion states that satisfaction in a given domain of life (e.g. housing) spills over into other domains of subjective well-being (e.g. satisfaction at work). The IV model is also estimated with establishment fixed and random effects.

Olley and Pakes (1996) introduced a semiparametric method that is able to tackle for both simultaneity and selection problems. Simultaneity arises in the estimation of production function, because firms usually choose their output level at the same time as they choose the set of inputs. Firms tend to increase the use of inputs as a result of positive production shocks. The selection effect emerges, because the exit process of firms from the market is not random. The central idea of Olley and Pakes (1996) is to use investment to proxy for an unobserved time-varying production shock. We modify the procedure in the following way. Rather than estimating a production function, we use total factor productivity directly as the dependent variable. We can think of job satisfaction as a stock variable that evolves slowly over time through the changes in job satisfaction of staying employees and through entry and exit of employees. We assume that the exit (outflow) of employees is a function of job satisfaction and productivity shocks. Low job satisfaction likely leads to voluntary quits or forced exits through layoffs. ${ }^{6}$ On the other hand, negative productivity shocks also increase exits. We assume that there is a monotonous inverse relationship between exits and the shocks. Then we can solve for the shocks as a function of satisfaction and exits and proceed otherwise in the same way as Olley and Pakes (1996). The selection problem is addressed by using the plant survival probabilities. We expect that the selection problem is less severe in our case than the simultaneity problem, because our panel covers a relatively short period of time (1996-2001).

\section{Results}

The baseline specifications for our three measures of productivity, based on OLS, are reported in Panel A of Table 1. The OLS estimates constitute a useful benchmark to which other results from more complex estimators can be compared. The baseline results reveal 
that one point increase in the average level of job satisfaction in the plant increases the level of value added per hours worked by $~ 5 \%$ in the manufacturing sector, other things being equal (Table 1, Panel A, Column 1). This is a very moderate effect quantitatively. Arguably, it is a very challenging task for plants to increase the average level of their employees' job satisfaction by one point, say from 4 to 5 , on a scale from 1-6, because there is a rather strong concentration of observations towards the higher end of the satisfaction scale. (The distribution of both job satisfaction and satisfaction with housing conditions is depicted in Figure 1.) To further illustrate the quantitative magnitude of the estimate it is useful to note that the average of absolute value of the annual changes in average job satisfaction in the manufacturing plants has been 0.026 units with standard deviation of 0.343 units over the period 1996-2001. Thus, one standard deviation increase in average job satisfaction in the plant increases labor productivity by some $1.6 \%$. To shed some light on the external validity of the results, it is useful to note that the estimate from the OLS model for capital stock per hours worked in manufacturing (not reported in the table) is reasonable $(\sim 0.25)$ and in accordance with the results obtained earlier in the literature for Finland (e.g. Lehto 2007). We also find that job satisfaction is not statistically significant determinant of total factor productivity in the manufacturing sector, not even at the $10 \%$ level (Table 1, Panel A, Column 2). ${ }^{7}$

Table 1 here

The estimates are both statistically and economically weaker when we use turnover per employee as our performance measure and include also non-manufacturing establishments to the model, compared to the use of value added per hours worked in the manufacturing sector (Table 1, Panel A, Column 3). The sample size increases substantially. The point estimate reveals that one point increase in the average level of employees' job satisfaction in the establishment increases turnover per employee by $\sim 3 \%$, but the estimate is statistically significant only at the $15 \%$ level. To explore the relevance of our third performance measure, we have also estimated the OLS model for turnover per employee for the manufacturing plants only (not reported in the table). Job satisfaction obtains the coefficient of 0.010 with robust standard error of 0.042 in this regression. Thus, job satisfaction is not related to turnover per employee, not even in the manufacturing sector. 
The relationship between the measures of productivity and the average level of job satisfaction is illustrated in Figure 2 by using added-variable plots (see Weisberg 1985). The idea of these plots is that the residuals from the fit "Y on all X's except $\mathrm{X}_{\mathrm{j}}$ ” (vertical axis) are plotted against the residuals from the fit “ $\mathrm{X}_{\mathrm{j}}$ on all the other $\mathrm{X}$ 's” (horizontal axis). In our case the added variable $\left(\mathrm{X}_{\mathrm{j}}\right)$ is the measure for job satisfaction. The added-variable plots in Figure 2 are based on the very same specifications that are reported in Panel A of Table 1. A linear trend in the plot points out that adding a linear term for job satisfaction predictor to the model is beneficial. Based on Figure 2 this is the case especially for the measure of labor productivity in manufacturing, i.e. job satisfaction contributes positively to plants' value added per hours worked. Also, these plots do not reveal any substantial number of outliers in the matched data.

Figure 2 here

To eliminate the time-invariant establishment effects, we follow the approach by Black et al. (2001:441) and Buhai et al. (2008:15-16), as described in the earlier section. The estimates show that one point increase in average job satisfaction increases the level of value added per hours worked by $\sim 13 \%$ (Table 1 , Panel B, Column 1). Thus, the magnitude of the point estimate, based on the 2-stage approach, is more than twice that of our OLS estimate for the manufacturing sector (Table 1, Panel A, Column 1). However, both of these estimates are within the same 95\% confidence intervals. The 2-stage results also reveal that the effect of job satisfaction on total factor productivity is not statistically significant, by a wide margin (Table 1 , Panel B, Column 2). The same pattern prevails for turnover per employee in all sectors (Table 1, Panel B, Column 3). Thus, the results based on the 2-stage approach support the pattern from the baseline OLS estimates according to which the connection between job satisfaction and establishment performance is tightest for labor productivity in the manufacturing sector. Therefore, we focus on the estimates for value added per hours worked in manufacturing in the following analysis.

The potential endogeneity of job satisfaction may cause a substantial bias in the OLS estimates. For example, employees with lower level of job satisfaction may be systematically matched with plants with high productivity (and high wages) in order to compensate for their inherently lower levels of satisfaction. Under this scenario, the OLS estimate would underestimate the true effect of job satisfaction on productivity. Indeed, we 
can clearly reject the null hypothesis of exogeneity of job satisfaction in the model for labor productivity in manufacturing by using Wu-Hausman test. ( $p$-value of the test is 0.021 .) Another apparent motivation for the use of IV estimator is the potential measurement error in job satisfaction. The OLS estimate for job satisfaction in the productivity equation is biased towards zero if there are random errors in the measure of job satisfaction, as pointed out by Mairesse and Greenan (1999).

The positive correlation between job satisfaction and satisfaction with housing conditions is illustrated in Figure 3. Formal tests confirm the visual pattern. The F-statistics for a test of the hypothesis that the coefficient on the instrument is zero in a regression of job satisfaction on the instrument is substantially higher (36.90) than the threshold of 10 proposed by Staiger and Stock (1997) for a weak instrument (Table 1, Panel C, Column 1). ${ }^{8}$ The F-test from a regression of residualized job satisfaction on the residualized instrument (44.21) is also well above 10. (The residualized values are obtained by taking into account the effects of establishment-level control variables and indicators, as listed in the Appendix, Table A1.) We have also estimated the OLS model for job satisfaction with satisfaction with housing conditions as one of the explanatory variables and including the control variables. In the model for manufacturing that corresponds to the first stage of IV estimation, satisfaction with housing conditions obtains the coefficient of 0.297 with robust standard error of 0.045 . Thus, one point increase in satisfaction with housing conditions increases job satisfaction by $\sim 0.30$ points, other things being equal.

Figure 3 here

The results based on the instrumental variable approach are reported in Panel C of Table 1. The IV estimate for the effect of job satisfaction on productivity is substantially larger than the one based on OLS. According to the IV estimate, one point increase in the average level of job satisfaction in the plant increases labor productivity by $20 \%$ in the manufacturing sector (Table 1, Panel C, Column 1). Therefore, the IV point estimate is roughly four times the OLS estimate. The economic size of the effect is still rather modest, because it is very difficult for a plant to increase the average level of job satisfaction for its employees by one point, on a scale 1-6, for the reason stated earlier. It is useful to note that the IV estimate is not particularly precise, because the 95\% confidence intervals for the IV estimate range from 0.050 to 0.364 . Thus, the baseline OLS estimate for labor productivity $(0.048)$ is 
almost included to the $95 \%$ confidence intervals of the IV estimate. The IV results also reveal that one point increase in job satisfaction improves total factor productivity by $~ 11 \%$ (Table 1, Panel C, Column 2). However, this estimate is statistically significant only at the $16 \%$ level. The results for all sectors confirm that job satisfaction is clearly not related to turnover per employee (Table 1, Panel C, Column 3).

Next we turn to the results based on the Olley-Pakes approach. We modify the standard Olley-Pakes approach, as described in the earlier section. We use total factor productivity directly as the dependent variable, job satisfaction as a state variable, and worker outflow as a proxy variable for unobserved time-varying productivity shocks. The control variables are the same as the ones for total factor productivity in Table 1 . To study the robustness of the results, we estimate the model both with and without taking into account the selection of plants over time. The baseline results that do not take the selection of plants into account show that job satisfaction obtains the coefficient of 0.035 with robust standard error of 0.007. (Hence, the estimate is statistically significant at the $1 \%$ level.) The standard error for the estimate is calculated by using bootstrapping with 250 replications. Thus, the point estimate based on the Olley-Pakes approach is very close to the estimate (0.036) that was obtained by using the baseline OLS model for total factor productivity in manufacturing (Table 1, Panel A, Column 2). However, the OLS estimate for total factor productivity was not statistically significant. We model the probability of plant survival as a function of lagged total factor productivity and plant size. The results remain the same in the specification that takes the plant survival probability into account. A prominent reason for this pattern is that our panel covers a relatively short period of time over which there has not been major turnover among the plants.

We have used several alternative estimators to explore the robustness of the results. We briefly summarize the results without showing them in tables. We have estimated the OLS model for value added per hours worked in manufacturing by using observations for only those establishments from which we have information on job satisfaction for at least two employees. The average job satisfaction in the plant obtains the coefficient of 0.073 with robust standard error of 0.053 . Thus, the point estimate is larger than the one in the baseline OLS model that uses all observations (Table 1, Panel A, Column 1). The fact that the point estimate is larger is consistent with the arguments in Mairesse and Greenan (1999). In addition, we have estimated conventional fixed effects models by including $\alpha_{\mathrm{j}}$ to the 
equation (1). Job satisfaction is not statistically significant determinant of productivity in any of those specifications. A prominent reason for this is that there is not enough variation in job satisfaction after taking within establishment differences. We have also estimated GMM panel data models in which we have experimented with the use of lagged values as instruments. However, the tests for overidentifying restrictions revealed that lagged variables are not valid instruments.

Moreover, we have estimated the 2-stage models that are reported in Panel B of Table 1 by instrumenting job satisfaction with satisfaction with housing conditions in the second stage. Using value added per hours worked as the dependent variable and data for manufacturing, the average job satisfaction in the plant obtained the coefficient of 0.269 with robust standard error of 0.119 . Job satisfaction was not statistically significant in the specifications for total factor productivity in manufacturing or turnover per employee for all sectors. Further, we have estimated IV models reported in Panel C of Table 1 with fixed effects and random effects. Job satisfaction does not obtain statistically significant positive coefficient in these models. Finally, we have also estimated the model for the manufacturing sector using the Olley-Pakes approach with value added per hours worked as the dependent variable. The model was otherwise similar as the one for total factor productivity, but capital intensity was added as another state variable. Job satisfaction obtained the coefficient 0.049 with robust standard error 0.013 . This estimate is very close to the one that we found by using OLS (Table 1, Panel A, Column 1).

\section{Conclusions}

We have explored the role of job satisfaction in the determination of establishment-level productivity. Our contribution is based on several extensions of the existing knowledge. We use the standard measures of productivity and representative data. The earlier studies have usually used various proxy variables for productivity and focused on narrow set of firms. In particular, we use matched survey and register data in which the measures of productivity and job satisfaction are taken from separate data sources. Therefore, the variables of interest are unrelated, by construction. In contrast, a strand of previous studies on the relationship between job satisfaction and performance has used subjective measures on the both sides of the estimated equation. We also implement an instrumental variable estimator that addresses the potential endogeneity of job satisfaction in the estimated equation. On the 
contrary, the existing studies have focused on the correlations between the variables of interest (see Judge et al. 2001). Furthermore, we apply the approach introduced by Olley and Pakes (1996) to estimate the model for total factor productivity in manufacturing.

The estimates for the effect of one point increase in the average level of employees' job satisfaction in the establishment, on a scale 1-6, on productivity vary depending on the specification of the model. Our preferred estimate, based on the IV estimation that uses satisfaction with housing conditions as instrument for job satisfaction, shows that the effect on value added per hours worked is $\sim 20 \%$ in the manufacturing sector. The magnitude of a realistic potential productivity improvement is, however, smaller. Arguably, it is very challenging for a plant to increase the average level of job satisfaction for its employees by one point, on a scale 1-6, because the observations on job satisfaction are bunched towards the higher end of the scale. The within-establishment standard deviation of the average job satisfaction measure that we used in the estimations is 0.33. Therefore, a one standard deviation improvement in establishment job satisfaction would improve productivity by 6.6 percent. It is also useful to note that the IV estimate for the effect of job satisfaction on labor productivity in manufacturing is larger than the one based on OLS. This demonstrates that it is important to address the potential endogeneity of job satisfaction in the estimated equation.

We also find that job satisfaction is not related to total factor productivity in manufacturing, according to both OLS and IV results. However, the estimates based on the Olley-Pakes approach reveal that job satisfaction is statistically significant determinant of total factor productivity in the manufacturing sector. Furthermore, job satisfaction is not positively related to turnover per employee in a larger sample that covers also non-manufacturing establishments. The pattern prevails in all estimated models. This is an interesting observation, because some of the earlier studies have used turnover or sales per employee as the measure of establishment performance. These findings call for more empirical studies that combine objective information on productivity from linked employer-employee data sources to subjective measures of employees' well-being. 
Table 1. The effect of job satisfaction on productivity.

\begin{tabular}{l|lll}
\hline & \multicolumn{2}{c}{ Dependent variable } \\
\cline { 2 - 3 } & $\begin{array}{l}\text { Value added per hours } \\
\text { worked }\end{array}$ & Total factor productivity & Turnover per employee \\
Sample & Manufacturing & Manufacturing & All sectors \\
\hline
\end{tabular}

Panel A: OLS

\begin{tabular}{l|lll}
\hline & $0.048 * *$ & 0.036 & 0.032 \\
& $(0.023)$ & $(0.026)$ & $(0.022)$ \\
$N$ & 737 & 737 & 2101 \\
\hline
\end{tabular}

Panel B: 2-stage approach

\begin{tabular}{l|lll}
\hline & $0.127 * * *$ & -0.0003 & 0.028 \\
& $(0.033)$ & $(0.061)$ & $(0.025)$ \\
$N$ & 523 & 624 & 2178 \\
\hline
\end{tabular}

Panel C: IV approach

\begin{tabular}{l|lll}
\hline & & & \\
F-statistic & 36.90 & 36.90 & 200.52 \\
Residualized F-stat. & 44.21 & 45.81 & 202.15 \\
IV estimate & $0.207 * * *$ & 0.109 & 0.053 \\
& $(0.080)$ & $(0.078)$ & $(0.066)$ \\
$N$ & & & 2101 \\
\hline
\end{tabular}

Notes: All nine models contain a full set of indicators for years, industries and regions. The models for the manufacturing sector contain all the unreported establishment-level control variables that are listed in the Appendix (Table A1). The models for all establishments contain the establishment-level control variables that are listed in the Appendix (Table A1) with the exception of the measure for capital stock and the indicator for exporters that are not available for the service sector. The 2-stage approach is based on fixed effects estimation and OLS, as explained in the text. The F-statistic refers to a test of the hypothesis that the coefficient on the instrument (i.e. satisfaction with housing conditions) is zero in a regression of job satisfaction on the instrument. Residualized F-statistic is taken from a regression of residualized job satisfaction on the residualized instrument, as explained in the text. Robust standard errors in parentheses: *statistically significant at the .10 level; **at the .05 level; ***at the .01 level. 
Figure 1. The Kernel density estimates for job satisfaction (JS) and satisfaction with housing conditions (HS).

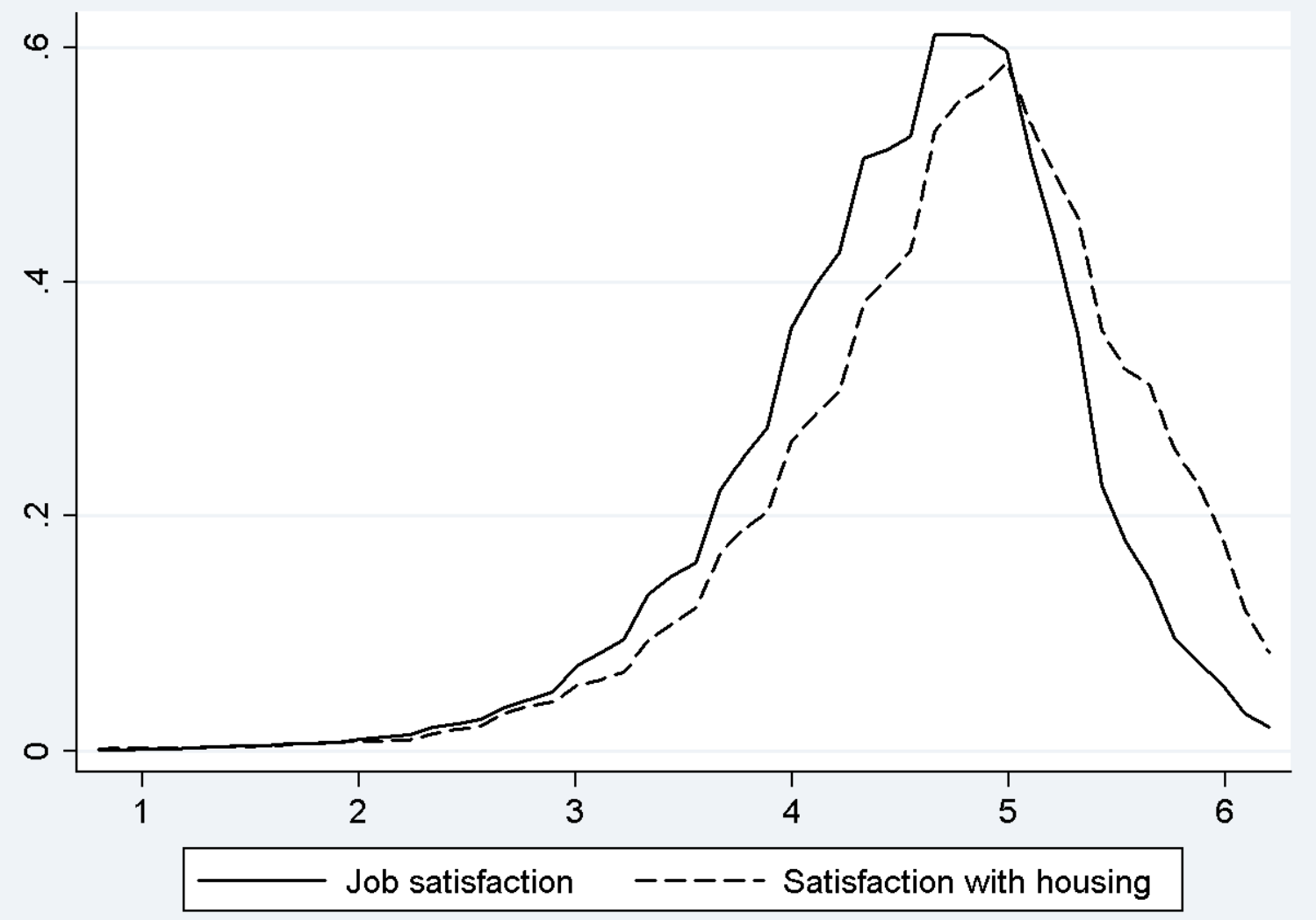

Notes: The figure shows Epanechnikov kernel densities with bandwidth 0.2. The satisfaction scores are threeyear averages for each establishment. The figure is drawn for all years and all sectors combined. 
Figure 2. The added-variable plots for job satisfaction.
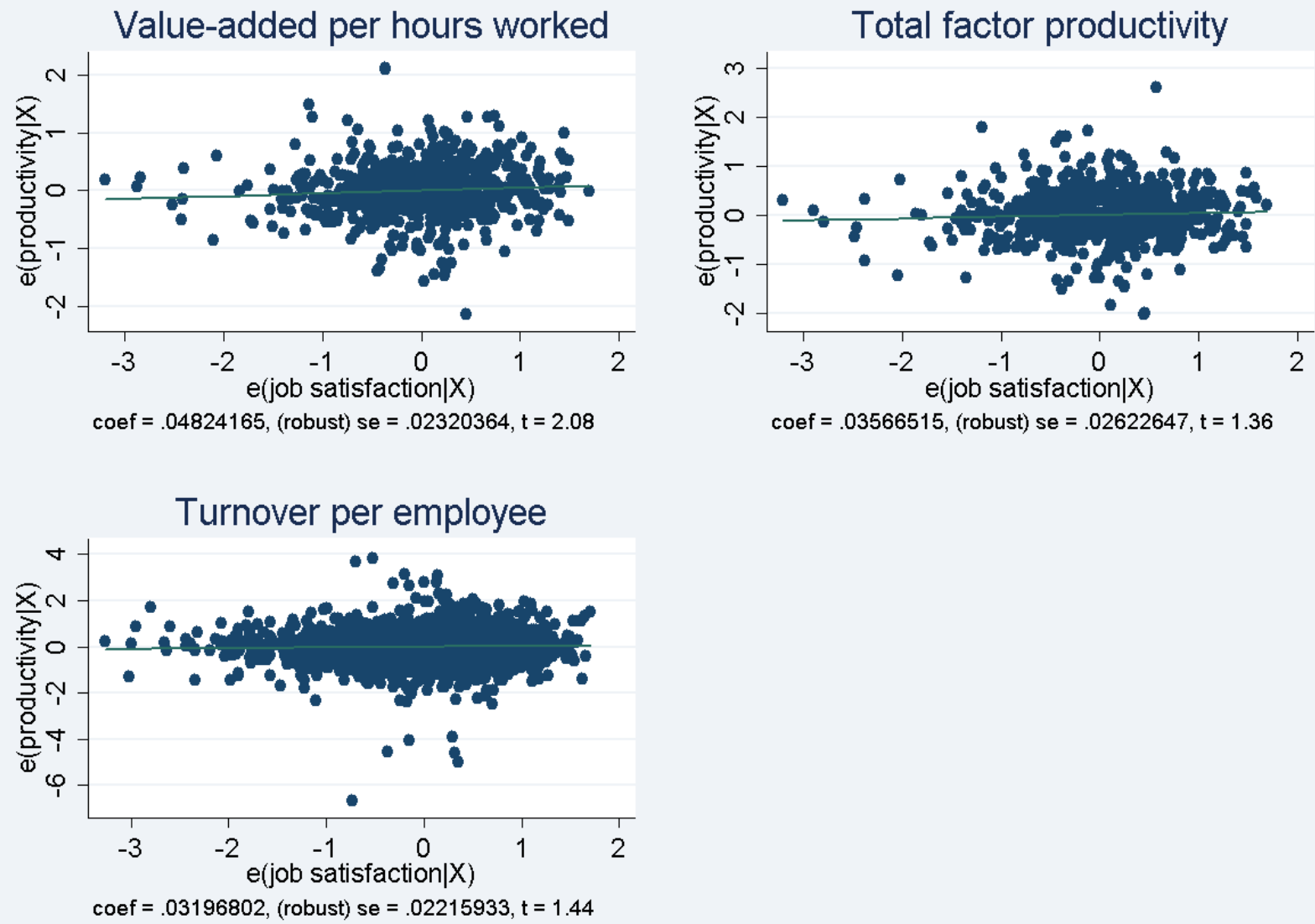

Notes: The upper left-hand panel is based on the specification for value added per hours worked in manufacturing (Table 1, Panel A, Column 1), the upper right-hand panel is based on the specification for total factor productivity in manufacturing (Table 1, Panel A, Column 2), and the lower left-hand panel is based on the specification for turnover per employee in all sectors (Table 1, Panel A, Column 3). Details are explained in the text. 
Figure 3. The relationship between job satisfaction (JS) and satisfaction with housing conditions (HS).

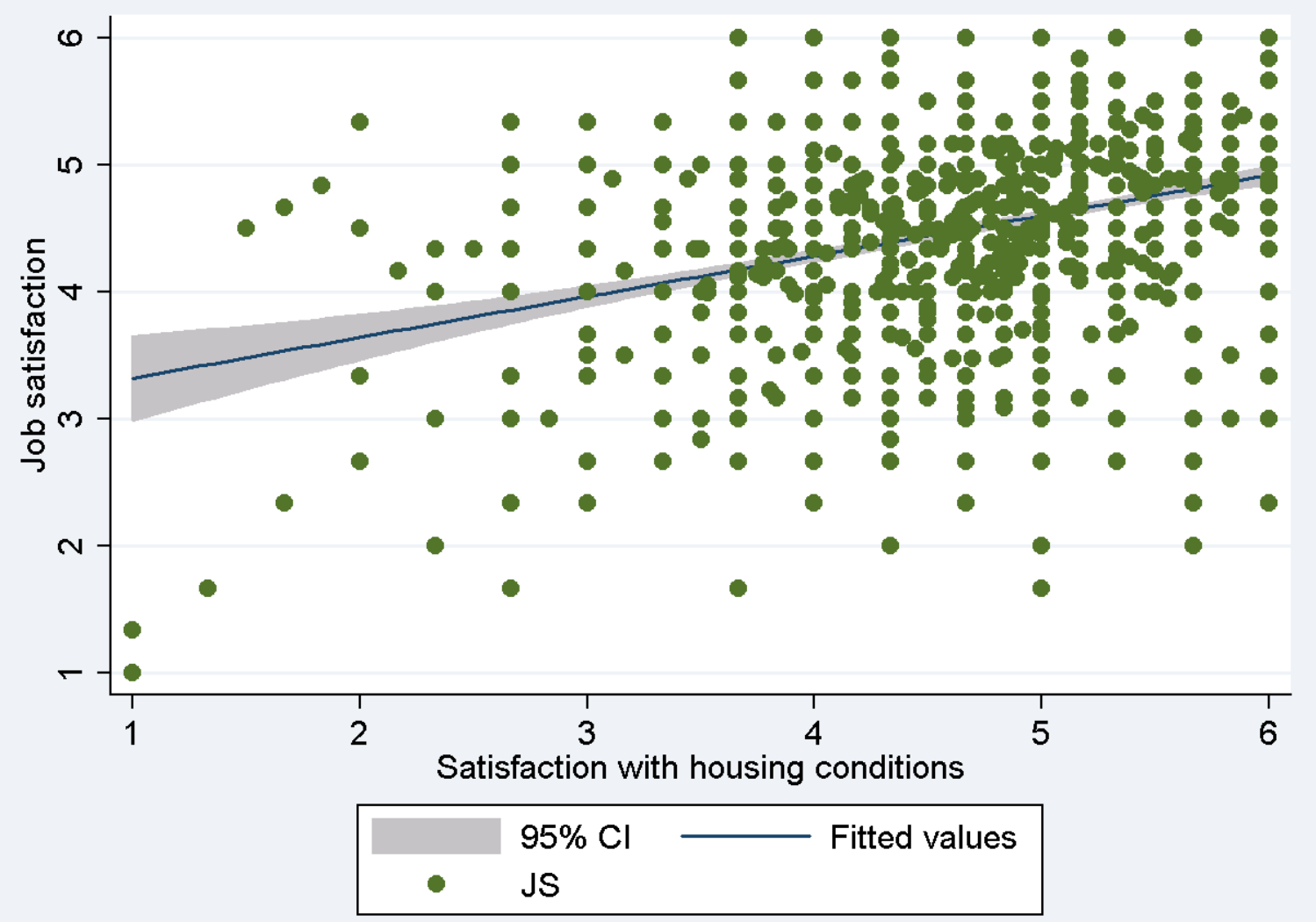

Notes: The $\mathbf{9 5 \%}$ confidence level is shaded. The figure is drawn for all years and all sectors combined. 


\section{References}

Black, Sandra E., and Lisa M. Lynch. 2001. "How to Compete: The Impact of Workplace Practices and Information Technology on Productivity.” Review of Economics and Statistics, Vol. 83, No. 3, pp. 434-445.

Buhai, Sebastian, Elena Cottini, and Niels Westergård-Nielsen. 2008. "The Impact of Workplace Conditions on Firm Performance.” Tinbergen Institute, Discussion Paper No. $077 / 03$.

Böckerman, Petri, and Pekka Ilmakunnas. 2009. “Job Disamenities, Job Satisfaction, Quit Intentions, and Actual Separations: Putting the Pieces Together.” Industrial Relations, Vol. 48, No. 1, pp. 73-96.

Clark, Andrew E. 1996. “Job Satisfaction in Britain.” British Journal of Industrial Relations, Vol. 34, No. 2, pp. 189-217.

Clark, Andrew E., Georgellis Yannis, and Peter Sanfey. 1998. "Job Satisfaction, Wage Changes, and Quits: Evidence from Germany.” Research in Labor Economics, Vol. 17, pp. 95-121.

Freeman, Richard. 1978. "Job Satisfaction as an Economic Variable.” The American Economic Review, Vol. 68, No. 2, pp. 135-141.

Glegg, Chris W. 1983. "Psychology of Employee Lateness, Absence and Turnover: A Methodological Critique and an Empirical Study.” Journal of Applied Psychology, Vol. 68, No. 1, pp. 88-101.

Hamermesh, Daniel. 2004. "Subjective Outcomes in Economics.” Southern Economic Journal, Vol. 71, Vol. 1, pp. 2-11.

Harter, James K., Frank L. Schmidt, and Theodore L. Hayes. 2002. "Business-Unit-Level Relationship between Employee Satisfaction, Employee Engagement, and Business Outcomes: A Meta-Analysis.” Journal of Applied Psychology, Vol. 87, No. 2, pp. 268-279.

Iaffaldano, Michelle T., and Paul M. Muchinsky. 1985. “Job Satisfaction and Job Performance: A Meta-Analysis.” Psychological Bulletin, Vol. 97, No. 2, pp. 251-273. Judge, Timothy A., Carl J. Thoresen, Joyce E. Bono, and Gregory K. Patton. 2001. “The Job Satisfaction-Job Performance Relationship: A Qualitative and Quantitative Review.” Psychological Bulletin, Vol. 127, No. 3, pp. 376-407.

Lehto, Eero. 2007. "Regional Impact of Research and Development on Productivity.” Regional Studies, Vol. 41, No. 5, pp. 623-638. 
Mairesse, Jacques, and Nathalie Greenan. 1999. "Using Employee-level Data in a Firmlevel Econometric Study.” In John C. Haltiwanger, Julia I. Lane, James R. Spletzer, Jules J.M. Theeuwes, and Kenneth R. Troske, eds., The Creation and Analysis of Employer-Employee Matched Data, pp. 489-512. Amsterdam: North-Holland.

Mangione, Thomas W., and Robert P. Quinn. 1975. “Job Satisfaction, Counterproductive Behavior, and Drug Use at Work.” Journal of Applied Psychology, Vol. 60, No. 1, pp. 114-116.

Mäki-Fränti, Petri. 2009. "Henkilöstön työkyky ja toimipaikkojen tuottavuus (Success of Companies and Work Ability of Personnel).” (In Finnish). Pellervo Economic Research Institute PTT, Working Paper No. 118.

Olley, G. Steven, and Ariel Pakes. 1996. "The Dynamics of Productivity in the Telecommunications Equipment Industry.” Econometrica, Vol. 64, No. 6, pp. 12631297.

Oswald, Andrew J., Eugenio Proto, and Daniel Sgroi. 2008. "Happiness and Productivity.” Warwick Economic Research Papers, No. 882.

Patterson, Malcolm, Michael West, Rebecca Lawthorn, and Steven Nickell. 1997. "Impact of People Management Strategies on Business Performance.” Institute of Personnel and Development, Issues in People Management No. 22.

Patterson, Malcolm, Peter Warr, and Michael West. 2004. “Organizational Climate and Company Productivity: The Role of Employee Affect and Employee Level.” Journal of Occupational and Organizational Psychology, Vol. 77, No. 2, pp. 193-216.

Peracchi, Franco. 2002. "The European Community Household Panel: A Review." Empirical Economics, No. 27, Vol. 1, pp. 63-90.

Rain, Jeffrey S., Irving M., and Dirk D. Steiner. 1991. “A Current Look the Job Satisfaction/Life Satisfaction Relationship: Review and Future Considerations.” Human Relations, Vol. 44, No. 3, pp. 287-307.

Schneider, Benjamin, Paul J. Hanges, D. Brent Smith, and Amy Nicole Salvaggio. 2003. "Which Comes First: Employee Attitudes or Organizational Financial and Market Performance?” Journal of Applied Psychology, No. 88, No. 5, pp. 836-851.

Staiger, Douglas, and James H. Stock. 1997. "Instrumental Variable Regression with Weak Instruments.” Econometrica, Vol. 65, No. 3, pp. 557-586.

Vanhala, Sinikka, and Kaija Tuomi. 2006. “HRM, Company Performance and Employee Well-being.” Management Revue: The International Review of Management Studies, Vol. 17, No. 3, pp. 241-255. 
Von Bonsdorff, Monika E., Minna Janhonen, Sinikka Vanhala, Päivi Husman, Pekka Ylöstalo, Jorma Seitsamo, and Erkki Nykyri. 2009. “Henkilöstön työkyky ja yrityksen menestyminen vuosina 1997-2007 - tutkimus metalliteollisuudessa ja vähittäiskaupan alalla (Personnel Work Ability and Companies' Performance in 1997-2007 - A Study of Metal Industry and Retail Trade).” (In Finnish). Finnish Institute of Occupational Health, Report No. 36.

Weisberg, Sanford. 1985. Applied Linear Regression. $2^{\text {nd }}$ Ed. New Jersey: John Wiley \& Sons, Inc.

Wilensky, Harold L. 1960. "Work, Careers and Social Integration.” International Social Science Journal, Vol. 12, No. 4, pp. 543-560.

Zelenski, John M., Steven A. Murphy, and David A. Jenkins. 2008. “The Happy-Productive Worker Thesis Revisited.” Journal of Happiness Studies, Vol. 9, No. 4, pp. 521-537. 


\section{Appendix}

Table A1. Definitions and descriptive statistics of the variables.

\begin{tabular}{|c|c|c|}
\hline Variable & $\begin{array}{l}\text { Mean } \\
\text { (standard } \\
\text { deviation) }\end{array}$ & Definition/measurement \\
\hline \multicolumn{3}{|l|}{ Dependent variables } \\
\hline Value added per hours worked & $\begin{array}{l}3.375 \\
(0.668)\end{array}$ & $\begin{array}{l}\text { Logarithm of value added divided by the hours worked in the } \\
\text { plant, deflated to the base year } 2000 \text { by using the price index for } \\
\text { value added from national accounts. The variable is not } \\
\text { available for the service sector (Source. LDPM) }\end{array}$ \\
\hline Total factor productivity & $\begin{array}{l}2.167 \\
(0.748)\end{array}$ & $\begin{array}{l}\ln T F P=\ln (Y / L)-(1-a) \ln (K / L) \text {, where } Y / L \text { is value added per } \\
\text { hours worked in the plant, } K / L \text { is capital stock per hours worked } \\
\text { in the plant, and } a \text { is the industry-level measure of the labor } \\
\text { share of the value added. } Y / L \text { and } K / L \text { are deflated to the base } \\
\text { year } 2000 \text {. Computation assumes constant returns to scale and } \\
\text { perfect competition. The variable is not available for the service } \\
\text { sector. (Source: LDPM and EU-KLEMS database). }\end{array}$ \\
\hline Turnover per employee & $\begin{array}{l}11.660 \\
(0.917)\end{array}$ & $\begin{array}{l}\text { Logarithm of turnover divided by the number of employees in } \\
\text { the establishment, deflated to the base year } 2000 \text { by using the } \\
\text { price index for gross production from national accounts (Source: } \\
\text { Business Register). }\end{array}$ \\
\hline \multicolumn{3}{|l|}{ Independent variables } \\
\hline Job satisfaction $(J S)$ & $\begin{array}{l}4.521 \\
(0.708)\end{array}$ & $\begin{array}{l}\text { The average job satisfaction level for the employees in the } \\
\text { establishment over the period } t, t-1 \text { and } t-2 \text {. Job satisfaction is } \\
\text { measured on an ordinal 6-point Likert scale from 'not satisfied' } \\
\text { to 'fully satisfied' (the question PK001). A higher value means } \\
\text { that a person currently feels more satisfied. (Source: ECHP) }\end{array}$ \\
\hline \multicolumn{3}{|l|}{ Control variables } \\
\hline Capital stock & $\begin{array}{l}2.989 \\
(1.451)\end{array}$ & $\begin{array}{l}\text { Logarithm of capital stock divided by the hours worked in the } \\
\text { plant. Capital stock is calculated by the perpetual inventory } \\
\text { method in which plant's past investments are accumulated } \\
\text { assuming that the depreciation rate is } 10 \% \text { and using the year } \\
2000 \text { prices. The variable is not available for the service sector. } \\
\text { (Source: LDPM). }\end{array}$ \\
\hline Vintage & .. & $\begin{array}{l}\text { The year of foundation of the establishment is recorded in seven } \\
\text { categories: -1976, 1977-1980, 1981-1985, 1986-1990, 1991- } \\
\text { 1995, 1996-1998 and 1999-2000. (Source: FLEED). }\end{array}$ \\
\hline Establishment size & .. & $\begin{array}{l}\text { The establishment size in terms of employees is recorded in six } \\
\text { categories: <=4, 5-9, 10-19, 20-49, 50-99 and }>100 \text {. (Source: } \\
\text { FLEED). }\end{array}$ \\
\hline The average age of employees & $\begin{array}{l}38.264 \\
(5.818)\end{array}$ & $\begin{array}{l}\text { The average age of all employees in the establishment. (Source: } \\
\text { FLEED/ES). }\end{array}$ \\
\hline The average years of education & $\begin{array}{l}11.437 \\
(1.314)\end{array}$ & $\begin{array}{l}\text { The average years of education of all employees in the } \\
\text { establishment (including all education levels). (Source: } \\
\text { FLEED/ES). }\end{array}$ \\
\hline $\begin{array}{l}\text { The average seniority of } \\
\text { employees }\end{array}$ & $\begin{array}{l}80.927 \\
(62.245)\end{array}$ & $\begin{array}{l}\text { The average seniority of all employees in the establishment } \\
\text { (measured in months). (Source: FLEED/ES). }\end{array}$ \\
\hline The female share & $\begin{array}{l}0.393 \\
(0.330)\end{array}$ & $\begin{array}{l}\text { The share of female employees in the establishment. (Source: } \\
\text { FLEED/ES). }\end{array}$ \\
\hline
\end{tabular}




\begin{tabular}{l|l|l} 
Exporter & $\begin{array}{l}0.211 \\
(0.408)\end{array}$ & $\begin{array}{l}\text { The share of exports of the value added in the plant is at least } \\
50 \%=1 \text {, otherwise 0. The variable is not available for the } \\
\text { service sector. (Source: LDPM). }\end{array}$ \\
$\begin{array}{ll}\text { Indicators } \\
\begin{array}{l}\text { Years (waves) } \\
\text { Industries }\end{array}\end{array}$ &.. & $\begin{array}{l}\text { Indicators for the years 1996-2001 } \\
\text { Indicators for 24 industries based on Standard Industry } \\
\text { Classification } \\
\text { Indicators for 6 NUTS2 regions }\end{array}$ \\
$\begin{array}{l}\text { Regions } \\
\text { Instrument for job } \\
\text { satisfaction }\end{array}$ & $\begin{array}{l}4.749 \\
\text { Satisfaction with housing } \\
\text { conditions (HS) }\end{array}$ & $\begin{array}{l}\text { The average level of satisfaction with housing conditions for the } \\
\text { employees in the establishment over the period } t, t \text {-1 and } t \text {-2. } \\
\text { Satisfaction with housing situation is measured on an ordinal 6- } \\
\text { point Likert scale from 'not satisfied' to 'fully satisfied' (the } \\
\text { question PK003). A higher value means that a person currently } \\
\text { feels more satisfied. (Source: ECHP) }\end{array}$
\end{tabular}




\footnotetext{
${ }^{1}$ Oswald et al. (2008) present evidence on happiness and productivity in piece-rate tasks using a randomized trial.

${ }^{2}$ There are earlier studies on the effect of employees' working capacity on firms' performance using Finnish data (Vanhala and Tuomi 2002; Mäki-Fränti 2009; von Bonsdorff et al. 2009). These studies focus on selected samples of firms and they do not address the potential endogeneity of employees' well-being.

${ }^{3}$ Finland was included in the ECHP for the first time in 1996 after she joined the European Union. The European Union stopped gathering data for the ECHP in 2001, which means that we have six waves of the data.

${ }^{4}$ The data set is described at http://www.euklems.net/.

${ }^{5}$ The number of person observations on job satisfaction per establishment in manufacturing is as follows: 1 person ( $\sim 55 \%$ of all establishments), 2 persons ( $\sim 25 \%), 3$ persons ( $\sim 8 \%), 4$ persons ( $\sim \%), 5$ persons ( $\sim \%)$, $\ldots$, and 12 persons $(\sim 0.2 \%)$. The distribution is quite similar for all sectors.

${ }^{6}$ E.g. Clark et al. (1998), and Böckerman and Ilmakunnas (2009) provide evidence that low job satisfaction predicts worker outflow.

${ }^{7}$ The control variables are same for all models in manufacturing.

${ }^{8}$ Because we are using only one instrument the F-values are squares of t-values.
} 